\title{
Extent of Awareness of Birth Control Methods and Their Use by Women in a Peri-Urban Area of Accra, Ghana
}

\author{
Kwabena Asomanin Anaman, Joana Okailey Aku Okai \\ Institute of Statistical, Social and Economic Research, University of Ghana, Accra, Ghana \\ Email: kwabenaasomanin@hotmail.com, kanaman@ug.edu.gh
}

Received 24 November 2015; accepted 16 January 2016; published 19 January 2016

Copyright (C) 2016 by authors and Scientific Research Publishing Inc.

This work is licensed under the Creative Commons Attribution International License (CC BY). http://creativecommons.org/licenses/by/4.0/

cC) (i) Open Access

\section{Abstract}

The rapid population growth and economic expansion in Ghana over the last decade have made the management of its population increasingly important necessitating detailed confidential studies on use of birth control methods. This paper reports a highly confidential survey-based study undertaken to assess the extent of awareness of and factors influencing the use of birth control methods among 120 women aged between 15 and 49 years, in their reproductive lifespan, at Abokobi, a suburb of Accra, Ghana. The analysis showed that age was the main factor responsible for the general level of awareness of birth control methods. The use of birth control methods was positively related to the level of awareness of birth control methods, being in a current sexual relationship, and the number of children that the woman had. Students were less likely to use birth control methods than non-students suggesting the need for more recognition of abstinence as an alternative birth control method.

\section{Keywords}

Birth Control, Contraceptives, Economics of the Family, Family Planning, Reproductive Decisions

\section{Introduction}

During earlier human civilisations, an issue of high value to human societies was the ability to reproduce and to have as many children as possible. The larger the number of children a woman procreates, the greater the level of respect for the individual. In this modern era, many people look beyond subsistence living and prefer a more leisured, relaxed life and hence increasingly fewer societies are holding on to this perspective of life. This has led to an increased demand for scientific means for controlling birth rates. Many people in the modern era, dat- 
ing from several centuries ago, have had the desire to decide when to have a child and when not to have one. In the modern era giving birth is one of the least motivating factors for people having sex especially for the unmarried who may want to have the pleasure of sex, but not with the intention of giving birth to children [1].

Contraceptives have been used in several forms for thousands of years throughout human history. A report by the United Nations Department of Economic and Social Affairs in 2011 indicates that the prevalence rate of contraceptive usage in the world increased from an average of $49.2 \%$ in 1980 to $62.7 \%$ in 2009. Sub-Saharan Africa which recorded an average prevalence rate of $11.2 \%$ in 1980 had its prevalence rate increased to $21.8 \%$ in 2009 [2]. However, many African women who need to avoid pregnancy and plan their families lack adequate access to modern contraceptive services. Modern contraceptive services are essential to women so that they can determine the size of their families, regulate childbirth and help to reduce maternal deaths and illnesses [3] [4].

A striking importance of birth control is the extent of pressure that large populations exert on economic and social facilities of a country. High levels of population create major limitations and constraints on economic progression and the ability of a country to make the necessary provision for the livelihood improvement of its citizens and the achievement of its national development targets and visions [5] [6]. For example, in Ghana, the annual growth rate of the population is $2.5 \%$ with the population doubling every 28 years. This high population growth puts pressure on infrastructure and public resources, especially in peri-urban and urban areas, around major cities such as Accra, the capital city of Ghana.

These peri-urban and urban areas in Ghana have even much higher population growth rates than the overall population growth rate of the country largely due to increasing rural-urban migration. For example, the Greater Accra region, one of the ten politically-administrative regions of Ghana, which hosts the national capital city, recorded a population of 4,010,054 in 2010, an increase from 491,817 in 1960, 851,614 in 1970, 1,431,099 in 1984, and 2,905,726 in 2000; an eight-fold increase over 50 years from 1960 to 2010, and an annual growth rate of 3.1\% between 2000 and 2010 larger than the $2.5 \%$ annual growth of the entire population. Of particular importance to this study is that while the population increase in urban areas is in a greater part largely due to migration as compared to natural birth increase, in the agriculturally-dominated peri-urban areas close to the cities, the natural population increase is more dominant than that due to migration [7] [8].

In Ghana, since political independence on 6 March 1957, various governments have pledged a commitment to improve the quality of life of the people through measures such as the reduction of maternal and infant mortality. The population policy of the country was clearly articulated and documented in 1969 [9] [10]. This policy re-emphasised population control and a decrease in the total fertility rate with the belief that it would accelerate economic development based on the improved ability to take care of children and the young [11]. The population policy developed in 1969 was revised in 1994. The revised policy aimed to decrease the proportion of women below 20 years and above 34 years having births to $50 \%$ by the year 2010 , decreasing to 80 percent rate by 2020 and also to make family planning services available, accessible and affordable to at least half of all adults by the year 2020. The use of contraceptives and birth control methods was to be a cornerstone of family planning services [9].

The prevalence rate of contraceptive use in Ghana increased from $12.9 \%$ in the 1980 s to about $24 \%$ in 2010 [12]. The Ghana Statistical Service (GSS) (2004) reports that, out of four married women, one does not want any more children; yet less than half of their needs to limit future births are being met. The use of contraceptives in Ghana appears to be increasing largely due to campaigns of various governments. Analysis by Ghana Health Service showed that an increasing number of people are accessing family planning services from the private suppliers like pharmacy shops and drug stores as a result of the ease for obtaining such products. These factors indicate that access to family planning is improving [12] [13].

Among women and men aged 25 - 29, the median age at first sexual intercourse was 18.3 years and 19.6 years respectively in 2003 [9]. This trend is also reported in the 2008 Ghana Demographic and Health Survey report which indicates that men start sexual activity at a median age of about 20 years while women start at 18.4 years [14]. In general, women engage in sexual activity at an earlier age than men. In Ghana, the number of females enrolled in schools is lower than that of male enrolment as reported by the 2010 Population and Housing Census [7]. This lower enrolment could possibly impact on the ability and willingness of women to access information relating to their ability to control their birth rate by using family planning methods. Better-educated women are more willing to engage in innovative sexual lifestyles than for people who are less educated [15] [16].

Better educated women are also thought of having more knowledge of birth control methods and also of ways to obtain them than people who are less educated because of the level of literacy and much more familiarity with 
modern institutions. For women especially, education has been seen as an important factor that promotes contraceptive usage in many developing countries like Ghana [17]. Awareness of contraception among women is therefore important and should be intensified to achieve the objective of reducing unplanned births.

While several research studies have been undertaken to assess the awareness and use of birth control methods by various groups of people in Ghana, the link between awareness of birth control methods and their use has not been fully analysed especially for low-income women in the child bearing age group. In particular, a distinction is needed to be made between general awareness of the existence of birth control methods, and specific awareness and information about the desirable attributes of the specific birth methods ideally required by women. Information about the desired attributes of birth control methods that meet the needs of women, especially those from low-income and disadvantaged backgrounds, must ultimately involve confidential personal-based surveys to elicit more accurate preferences of women in order to shape more appropriate policies.

The main objective of the study was to assess the extent of awareness and use of birth control methods by potentially child-bearing women between 15 to 49 years in Abokobi, a peri-urban, low-income area of Accra. The rest of the paper is organised as follows: the next section focuses on the review of relevant literature review followed by the presentation of the methodology. The results of the study are discussed in the fourth section. The conclusions and recommendations follow.

\section{Literature Review}

\subsection{Definition and Types of Birth Control Methods}

Birth control is the planned control of the birth rate by methods that prevent the conception of individuals [18]. Birth control is also defined as the spacing of children given birth to by individual families within a reasonable time period which helps the mother to give adequate care and effective weaning to a child before giving birth to another one. Birth control and family planning are often used interchangeably [19]. While birth control may be viewed as reducing the number of children a person may give birth to; family planning is equally perceived as scheduling or restructuring how to go about giving birth to a reasonable sizeable and manageable number of children by individual family units. In whichever case the essence of birth control or family planning is to give birth to a number of children which the individual family can take care of adequately [19].

Birth control methods are categorized into three groups based on their effectiveness and the nature of the products. These three groups are 1) long-acting contraceptive methods involving invasive procedures inside the human body such as surgery or implants which are reversible or non-reversible, 2) hormonal methods which are less invasive and have medium contraceptive impact, and 3) barriers and natural methods [20]-[22]. The first group of contraceptive methods which involve invasive procedures and have long-term acting effects includes implants, intra-uterine device (IUD), male sterilisation, female sterilisation and abortion. The second group consists of methods which involve minimal to modest invasive procedures into the human body and are largely hormonal in nature. This group includes injectable medicine, female pill and emergency contraceptive drug or pill. The third group, barriers and natural methods, includes condoms, rhythm or calendar method, foaming tablets and traditional birth control method based on planned abstinence of the woman from her husband or partner.

\subsection{Awareness and Use of Birth Control Methods}

The Cambridge Dictionary of the English language defines awareness as knowledge that something exists; or an understanding of a situation or subject based on the available information and experience. Basic information that a product exists is at the lower end of an awareness continuum scale for a product; at the higher end of the awareness continuum scale is high level of familiarity of the product including its prior use. Awareness of birth control methods is therefore the logical first step necessary for their use by women. Since intensity of awareness is related to the available information and experience, the extent of use of birth control methods is also dependent on the intensity of awareness of these methods.

Birth control methods play a crucial role in population management, poverty alleviation, and human development. Effective birth control methods have a wide range of benefits. These benefits include increased maternal and child survival, improved nutrition, better educational prospects, increased possibility of girls and women getting into places of authority both at home and in society, and the prevention of sexually-transmitted infections 
[23] [24]. It is worthy of note that a certain level of awareness usually precedes the use of a particular birth control method. A certain level of awareness usually precedes the use of a particular birth control method. Factors influencing awareness of birth control methods identified in research works include locational endowment, personal factors such as education and age, economic factors as well as social and cultural factors [25].

Awareness of birth control methods especially contraceptives is high in Ghana. The 2003 Ghana Demographic and Health Survey (GDHS) confirmed this assertion by reporting that about 98 percent of women and about $99 \%$ of men had heard of at least one modern method of contraception. In the 2008 GDHS about $17 \%$ of married women used a modern method of family planning with an additional $7 \%$ using a traditional method. Injectable (6\%) was the most frequently used method. This was followed by the pill; it was recorded that $5 \%$ of married women aged 15 to 49 years used this product in 2008 [12].

In a survey conducted among teenage pregnant women in Nigeria, there was a high level of general awareness as high as $91.7 \%$ among the women. This result showed the explorative instincts of youth hence their high level of awareness on birth control methods. From the study, the male condom and the combined oral pill ranked highest in terms of awareness. Despite the high level of general awareness of birth control methods, the use of more complicated methods was rare. The majority of youth who were aware of birth control methods received information from friends [26]. However, health workers were the major source of information on emergency contraception in Ghana [27]. The limitation of the latter study was that it failed to categorize the awareness related to the age of respondents; this categorisation could have possibly revealed the dependency of teenagers and youth on friends in terms of knowledge of contraception. In a population, the more innovative groups such as the younger, educated urban women were first to become aware of and also the first to use various contraceptives [28] [29].

There was a low level of patronage of contraceptives in city slums in Kenya. This was possibly be due to the fact that residents lived in poor conditions with low level of education and therefore did not appreciate contraceptive usage as compared to those who are were rich and well educated [30]. Educational attainment and employment status were some of the major factors influencing the use of birth control methods in Ghana. This was because education increases people's responsiveness and understanding of birth control methods. Employment status was identified as a major influence on the use of birth control methods as it related to urban working women who were busy following professional development path and were less likely to produce children as compared to non-professional women based in rural areas [29].

Religious beliefs have also been found as major factor that influences people's use of birth control methods. Fundamentalist adherents of some religions believe that child birth is a natural process ordained by God and therefore should not be hindered by any means. These fundamentalist believers are less likely to use contraceptives as established in some parts of Nigeria [31]. Husband-wife agreement, and spousal power relations can also influence use of contraceptives by women especially under marriage situations. Such power relations tend to be less important in non-marriage situations such as those involving career-minded young women who are unmarried and have consensual relations with men. The analysis of the influences of power relationships, within marriage and informal unions, on the use of contraceptives by women show mixed results [32].

\subsection{Desirable Attributes of Birth Control Methods}

Birth control methods or contraceptives are essentially products desired by people to use for particular purposes. From an economics viewpoint, any product demanded by people can be considered as a mix of desirable attributes or characteristics. It is the attributes of the product that the consumers demand [33]. For the case of contraceptive, a critical attribute is adequate information about the product. Desirable attributes of contraceptives suggested by low-income women in Mexico included minimization or absence of unpleasant side effects, effectiveness in avoiding pregnancy, partner acceptance which is related to the power-relation within the familystructure, and ease in inserting items into the human body. Other studies established that the three most important attributes required by women of demanded products were 1) effectiveness, 2) lack of side effects and 3) affordability [34] [35].

Affordability is important as enhanced family planning services targeted at low-income and rural people need to incorporate this attribute for sustainable use of these services [35] [36]. Availability and accessibility are also considered to be important attributes of birth control methods that are desired by women. Availability connotes the presence of a product in a particular community of women; however accessibility is related to the ease that 
the woman can use the product and deals with the physical presence of a place to get the product and the amount of time that it takes to get to the place to get the product [37]. Other important attributes of birth control methods include their ability to prevent or minimize sexual infections and diseases from partners, self-administered means that reduce the need of trained medical personnel. The minimization and absence of side effects are also important desirable attributes of birth control methods. The side effects of various birth control methods, including probable acquisition of diseases from the partner, have been documented [38].

\section{Methodology}

\subsection{Description of Survey Procedures and Administration}

The unit of analysis for the research study was females between the ages of 15 and 49 years at Abokobi, the capital town of the Ga East Municipal Assembly in the Greater Accra region of Ghana. The survey focussed geographically on the Abokobi township and involved the use of residential houses as the means through which the females could be contacted as these houses provided evidence of residential status of the respondents. Further given that the Government authorities do not have detailed information about people living in the area, the use of houses is the appropriate tool as these authorities, such as the local government District Assembly, has information on the number of houses in Abokobi Township. The survey of houses at Abokobi involved the scientific sampling procedures using the multi-stage cluster sampling procedures as used in Ghanaian and overseas contexts [39]-[42].

The sampling procedures were based on selecting an optimal size of 101 houses out of the total 404 houses in Abokobi as at the time of the survey. The desired maximum sampling error was $10 \%$. The minimum optimal size (n) of 101 was chosen based on a formula given as $n=N / 1+N(e)^{2}$ where $N$ is the total number of households and e is the margin of error (assumed to be $10 \%$ for this study) [43].

The survey was conducted over a period of five months from February to June 2014. A scientific calculator was employed using random sampling to choose randomly houses located in the eight different clusters. The houses in the clusters were numbered sequentially for easy tracking to avoid duplication. All women between the ages of 15 to 49 who were located in the randomly selected houses and were willing to participate in the study were interviewed. In two of the 101 houses, the contacted women were very busy with commitments and declined to be interviewed. Thus the 120 women interviewed came from 99 houses; 78 women came from single-household houses, and the remaining 42 women were from 21 houses that contained at least two households. The interviews were conducted based on ethical guidelines involving voluntary participation and clearlyexpressed consent, and undertaken in the appropriate local Ghanaian language understood by the respondent.

The final questionnaire was developed after the pilot survey and it consisted of six main sections. Section A of the questionnaire captured general information on population and birth control methods in the Municipality. This section elicited the perceptions of respondents on birth control to control population. Section B dealt with the awareness of the different birth control methods. Section $C$ focused on the use of birth control methods by the respondents. Section D requested details of the use and non-use of birth control methods. Section E elicited data relating to current use of birth control methods. Section F, the last component, asked questions related to the socioeconomic characteristics of the respondents including age, income level, education and marital status.

\subsection{Empirical Estimation of Models}

The summary of the literature review suggests that in generality the use of birth control methods by adult women is dependent on the intensity of awareness of these products, and the attributes that are embodied in them. Other socio-economic factors such as age, education, employment, status, location and religiosity exert important influences on the use of birth control methods. A certain minimum amount of awareness about a birth control method is necessary before a woman can use the method. Hence, we use the generalisation of the Tobit model [44] to analyse the factors influencing awareness and use of birth control methods by women at Abokobi based on the sample selection model developed originally by Heckman [45]. The Tobit model is a one-stage estimation procedure while the generalized Tobit model of Heckman is a two-stage estimation procedure.

For the generalized Tobit model, in the first stage, a Probit equation model was used to estimate the likelihood of a woman using birth control methods. This first stage was dependent on the second stage model which was a multiple regression model dealing with factors influencing the level of general awareness of recognized birth 
control methods. It is postulated that the likelihood of using birth control methods was dependent on the level of awareness of birth control methods. The first-stage probit model is described in Equation (1).

$$
\text { EVERUSEBCM }=\mathrm{B}_{0}+\mathrm{B}_{1} \text { CSEXRELA }+\mathrm{B}_{2} \text { AWARENESS } 2+\mathrm{B}_{3} \text { EDU }+\mathrm{B}_{4} \mathrm{NCHILD}+\mathrm{B}_{5} \text { STUDENT }+\mathrm{V}_{1}
$$

where EVERUSEBCM was a dummy variable with 1 representing women who had ever used birth control methods (BCM) including those currently using BCM, and zero otherwise;

CSEXRELA was a dummy variable with 1 representing those who had current sexual relationships at the time of the survey and zero otherwise;

AWARENESS2 was the score of importance of awareness of the seven major birth control methods actually used by the respondents. These were 1) dual protection with the male wearing condom, 2) rhythm or calendar method, 3) withdrawal before ejaculation, 4) illegal abortion, 5) female pill, 6) injectable medicine and 7) emergency contraception. The scoring index was based on the zero to five Likert-type scale of awareness with 5 presenting the highest value of importance and zero representing complete lack of awareness;

EDU was the number of years of formal educational attainment of the respondent;

NCHILD was the number of children produced by the respondent;

STUDENT was a dummy variable with 1 representing respondents who were students at the time of the study and zero otherwise; and $\mathrm{V}_{1}$ was the equation error term.

The second-stage awareness of birth control methods model is described in Equation (2).

$$
\text { AWARENESS1 }=\mathrm{C}_{0}+\mathrm{C}_{1} \mathrm{AGE}+\mathrm{C}_{2} \text { EDU }+\mathrm{V}_{2}
$$

where AWARENESS1 was the average level of importance of awareness of the identified 18 birth control methods except the traditional abstinence method (used by 12 respondents). The scoring index was based on the zero to five Likert-type scale of awareness with 5 presenting the highest value of importance and zero representing complete lack of awareness;

AGE is the age of the woman respondents; and $V_{2}$ is the equation error term.

The above two equations (Equation (1) and Equation (2)) were connected by estimating a correlation $(\rho)$ between their error terms, $V_{1}$ and $V_{2}$. The two equations were jointly estimated using the SAMPSEL command based on the Time Series Processor (TSP) software [46].

\section{Results}

\subsection{Socio-Economic Characteristics of Survey Respondents}

Table 1 provides a summary of the socio-economic characteristics of the respondents who participated in the survey. About $45.8 \%$ of respondents were single, 35\% were married, $5.8 \%$ had been divorced, $3.3 \%$ were widows, $9.2 \%$ were found to be in informal unions and $0.8 \%$ had separated from the partner. The study area is dominated by Christians. About $46.7 \%$ of the respondents were in the 15 - 25 years of age range while $34.2 \%$ were in the 26 - 37 years of age category. Another important socio-economic characteristic was the level of education attained. Almost half of the respondents had completed junior high school or its equivalent, $11.9 \%$ had completed some level of senior high school education but could not complete senior high school while $6.8 \%$ of the respondents had graduated from the senior high school and 5.1\% had completed undergraduate university educational programmes. About $42.5 \%$ of the respondents were self-employed $19.2 \%$ were students, $8.3 \%$ were government sector employees, $14.2 \%$ were employed in the private sector while $1.7 \%$ were artisans.

Table 2 reports average figures of selected socio-economic characteristics of respondents. The mean age for the whole group was approximately 28 years implying a youthful population. The average household size was approximately five. The number of male children born per woman was 0.8 while female children was 0.7 indicating slightly greater number of males to females born. The average total monthly personal income of respondents was about 700 Ghana Cedis (GHC). The average household income was GHC 1650. On average, 2.94 Ghana Cedis were worth one United States dollar in 2014.

\subsection{Overview of Awareness of Birth Control Methods}

The study identified 18 specific methods of birth control as follows: 1) Male condom, 2) Illegal abortion, 3) Female condom, 4) Injectable medicine, 5) Rhythm or calendar method, 6) Female pill, 7) Legal abortion, 8) Withdrawal before ejaculation, 9) Implant, 10) Emergency contraception pill, 11) Female sterilization, 12) Traditional herbs, 
Table 1. Percentage of the 120 study participants based on their summary of socio-economic characteristics.

\begin{tabular}{|c|c|}
\hline Item/group & Percentage (\%) \\
\hline \multicolumn{2}{|l|}{ Age group } \\
\hline $15-20$ & 19.9 \\
\hline $21-25$ & 26.6 \\
\hline $26-30$ & 15.0 \\
\hline $31-35$ & 18.4 \\
\hline $36-40$ & 9.1 \\
\hline $41-45$ & 6.7 \\
\hline $46-49$ & 4.2 \\
\hline \multicolumn{2}{|l|}{ Marital status } \\
\hline Single & 45.8 \\
\hline Married & 35.0 \\
\hline Informal unions & 9.2 \\
\hline Divorced & 5.8 \\
\hline Widowed & 3.3 \\
\hline Separated & 0.8 \\
\hline \multicolumn{2}{|l|}{ Educational level } \\
\hline No formal education & 4.2 \\
\hline Primary school & 7.6 \\
\hline Junior high school & 49.2 \\
\hline Some senior high school & 11.9 \\
\hline Completed senior high school & 6.8 \\
\hline Technical college/school & 1.7 \\
\hline Diploma & 4.2 \\
\hline Higher National Diploma & 5.9 \\
\hline Bachelor degree & 5.1 \\
\hline Other certificate & 3.4 \\
\hline \multicolumn{2}{|l|}{ Occupation } \\
\hline Self-employed/own business & 42.0 \\
\hline Others such as student & 19.3 \\
\hline Private sector employee & 14.3 \\
\hline Unemployed & 13.4 \\
\hline Government sector employee & 8.4 \\
\hline Artisan & 1.7 \\
\hline Farmer & 0.8 \\
\hline
\end{tabular}

Table 2. Summary of socio-economic characteristics of survey respondents based on averages.

\begin{tabular}{ccc}
\hline Item & Mean & Standard deviation \\
Age (years) & 28.3 & 9.3 \\
Total personal income of respondents per month, Ghana Cedis (GHC) & 700.0 & 8.3 \\
Total household income of respondents per month (GHC) & 1650.0 & 5.0 \\
Number of people in the household & 1.5 & 3.0 \\
Number of children & 0.8 & 1.9 \\
Number of male children including living and those dead & 0.7 & 1.2 \\
Number of female children including living and those dead & 1.0
\end{tabular}

13) Intra-uterine device (IUD), 14) Foaming tablet, 15) Men taking drugs to prevent pregnancy, 16) Male sterilization, 17) Breastfeeding method and 18) Traditional Ghanaian birth control method based on planned abstinence of the woman from her partner/spouse, for a few months and up to one year or more, after delivery of a baby.

Table 3 presents the average score of awareness of each of the 18 identified birth control methods based on a Likert-scale scoring index from 0.0 to 5.0, with 0.0 indicating total lack of awareness of the birth control method and 5.0 the maximum level of awareness of the method. The seven most familiar methods of birth control were 1) male condom, 2) illegal abortion, 3) female condom, 4) injectable medicine, 5) rhythm or calendar method, 
Table 3. Ranking of the level of awareness of birth control methods by respondents.

\begin{tabular}{|c|c|c|c|c|c|}
\hline No. & Method & No. & $\begin{array}{l}\text { Average score } \\
\text { of importance }\end{array}$ & $\begin{array}{l}\text { Standard deviation } \\
\text { of score }\end{array}$ & $\begin{array}{c}\text { Coefficient of } \\
\text { variation }\end{array}$ \\
\hline 1. & Male condom & 120 & 4.85 & 0.806 & 0.166 \\
\hline 2. & Illegal abortion & 120 & 4.77 & 0.837 & 0.175 \\
\hline 3. & Female condom & 120 & 4.58 & 1.275 & 0.278 \\
\hline 4. & Injectable medicine & 120 & 4.46 & 1.334 & 0.299 \\
\hline 5. & Rhythm or calendar & 120 & 4.43 & 1.493 & 0.337 \\
\hline 6. & Female pill & 120 & 4.30 & 1.510 & 0.351 \\
\hline 7. & Legal abortion & 120 & 4.22 & 1.711 & 0.405 \\
\hline 8. & Withdrawal before ejaculation & 120 & 3.94 & 1.972 & 0.501 \\
\hline 9. & Implant & 120 & 3.86 & 1.984 & 0.514 \\
\hline 10. & Emergency contraception pill & 120 & 3.76 & 2.080 & 0.554 \\
\hline 11. & Female sterilization & 120 & 3.40 & 2.243 & 0.660 \\
\hline 12. & Traditional herbs & 120 & 3.17 & 2.349 & 0.741 \\
\hline 13. & IUD/coil/diaphragm & 120 & 3.01 & 2.310 & 0.767 \\
\hline 14. & Foaming tablet & 120 & 2.75 & 2.359 & 0.858 \\
\hline 15. & Men taking drugs to prevent pregnancy & 120 & 2.52 & 2.394 & 0.950 \\
\hline 16. & Male sterilization & 120 & 2.08 & 2.407 & 1.157 \\
\hline 17. & Breastfeeding method & 120 & 2.07 & 2.354 & 1.137 \\
\hline 18 & $\begin{array}{l}\text { Traditional birth control based on planned } \\
\text { abstinence from husband }\end{array}$ & 120 & 0.18 & 0.907 & 5.039 \\
\hline
\end{tabular}

Notes: The scoring is based on 5 denoting that item is very high level of awareness, 4 represented high level of awareness, 3 indicated moderate level of awareness, 2 represented low level of awareness, 1 represented very low level of awareness and 0 represented total lack of awareness of the particular birth control method. The coefficient of variation is the standard deviation divided by the mean score.

6) female pill and 7) legal abortion. All these seven methods were ranked above 4.0 in terms of the awareness intensity index, in the high awareness range.

The next six most familiar methods, in the moderate to high awareness range from 3.0 to 4.0, were 8) withdrawal before ejaculation method, 9) implant, 10) emergency contraception pill, 11) female sterilization, 12) traditional herbs and 13) IUD. The birth control methods considered to be lowly important in terms of level of awareness were 14) foaming tablet, 15) men taking drugs to prevent pregnancy, 16) male sterilization, 17) breastfeeding method, and 18) traditional birth control involving planned abstinence of the woman from her husband, which was known by only 12 women ( $10 \%$ of the sample).

\subsection{Sources of Awareness and Information about Birth Control Methods}

Table 4 summarises the declared major sources of awareness of the five birth control methods which are longacting and involve bodily-invasive procedures. Hospitals and clinics were the most important sources of information for implants, IUD and female sterilisation while peers and friends were the most important sources for both illegal and legal abortions. Television advertisements, sex education in schools and radio were considered moderately important sources of information for several birth control methods. The major sources of awareness for the hormonal methods are reported in Table 5. Peers and friends were the most important source of information for emergency contraceptive pill, traditional herbs and men taking hormonal medicine to prevent pregnancy. However, hospitals and clinics were also important sources of information, being the most important for injectable medicine and the second most important for the female pill and emergency contraceptive pill. Television advertisements were the most important source of information for the female pill reflecting the publicity campaigns of government agencies. Radio was an important source for men taking hormonal medicine. Sex education in schools was an important source of information for traditional herbs and men taking hormonal medicine. 
Table 4. Respondents' declared major sources of awareness or information on the five birth control methods which are longacting and involve bodily-invasive procedures using frequency analysis.

\begin{tabular}{cccc}
\hline Birth control method & $\begin{array}{c}\text { First most important source } \\
\text { of information }\end{array}$ & $\begin{array}{c}\text { Second most important source } \\
\text { of information }\end{array}$ & $\begin{array}{c}\text { Third most important source of } \\
\text { information }\end{array}$ \\
\hline Implants & Hospitals and clinics (64.6\%) & Peers and friends (24.2\%) & Television advertisements (19.2\%) \\
IUD & Hospitals and clinics (57.5\%) & Television advertisements (26.4\%) & Peers and friends (23.0\%) \\
Female sterilisation & Hospitals and clinics (48.8\%) & Peers and friends (23.8\%) & Sex education in schools (17.9\%) \\
Illegal abortion & Peers and friends (61.8\%) & Sex education in schools (15.3\%) & Radio (11.7\%) \\
Legal abortion & Peers and friends (44.3\%) & Hospitals and clinics (25.2\%) & Special television programmes (15.0\%) \\
\hline
\end{tabular}

Note: The figures in parentheses are the proportions of respondents using that information source.

Table 5. Respondents' declared major sources of awareness or information on the five identified hormonal methods with medium term impact using frequency analysis.

\begin{tabular}{|c|c|c|c|}
\hline Birth control method & $\begin{array}{l}\text { First most important } \\
\text { source of information }\end{array}$ & $\begin{array}{l}\text { Second most important } \\
\text { source of information }\end{array}$ & $\begin{array}{l}\text { Third most important } \\
\text { source of information }\end{array}$ \\
\hline Injectable medicine & Hospitals and clinics (60.5\%) & $\begin{array}{l}\text { Television advertisements } \\
\text { (36.8\%) }\end{array}$ & Peers and friends (21.1\%) \\
\hline Female pill & $\begin{array}{l}\text { Television advertisements } \\
\text { (55.3\%) }\end{array}$ & Hospitals and clinics (48.2\%) & Peers and friends (34.2\%) \\
\hline Emergency contraceptive pill & Peers and friends (36.5\%) & Hospitals and clinics (35.5\%) & Television advertisements (32.3\%) \\
\hline Traditional herbs & Peers and friends (54.2\%) & $\begin{array}{l}\text { Parents, carers and older } \\
\text { relatives }(20.9 \%)\end{array}$ & Sex education in schools (9.8\%) \\
\hline $\begin{array}{l}\text { Men taking hormonal and related } \\
\text { medicine to prevent pregnancy. }\end{array}$ & Peers and friends (70.2\%) & Radio (21.0\%) & Sex education in schools (7.5\%) \\
\hline
\end{tabular}

Note: The figures in parentheses are the proportions of respondents using that information source.

As reported in Table 6, for the identified barriers and natural methods, the key sources of information were television advertisements, hospitals and clinics, peers and friends, and sex education in schools. Of particular importance is the role of television advertisements in being the most popular sources of information for both the male and female condoms. Another important result from Table 6 is the relative low importance attached to hospitals and clinics as a source of information for the traditional method of planned abstinence.

\subsection{Overview of the Use of Birth Control Methods by Respondents}

Forty out of the 120 respondents indicated that they had never used any of the 18 birth control methods that involved sexual intercourse with a partner (see Table 3). The other 80 respondents had used one or more of the 18 birth control methods either in the past or during the time of the survey involving sex with a partner. Out of the 80 respondents who had ever used a birth control method, 32 (40\%) were using a birth control method for the first time during the previous 12 months preceding the survey that involved sex with a partner. Four more women were using a birth control method at the time of the survey but were not involved in sex with a partner as they were taking preventive action to avoid pregnancy in the case of a future sexual intercourse encounter. Thus 84 people or $70 \%$ of the 120 respondents had ever used one or more of the 18 birth control methods.

Table 7 reports on the popularity of specific birth control methods in terms of actual use by respondents over two periods of time: within the 12 months preceding the survey and more than 12 months preceding the survey. The most popular birth control method that was currently used (within 12 months before the survey) was the rhythm or calendar method with $42.5 \%$ of birth control users applying this method. The next most popular methods in terms of current use were withdrawal before ejaculation (41.2\%), dual protection with the use of male condom (21.7\%) and injectable method (8.5\%). In terms of past use of birth control methods (more than 12 months before preceding the survey), dual protection with the use of male condom (30.5\%) was the most popular method followed by illegal abortion (18.5\%), female pill (17.1\%), withdrawal before ejaculation (11.1\%) and rhythm or calendar method (10.8\%). The least popular methods of birth control methods used by respondents were female sterilisation, men taking hormonal and related medicine to prevent pregnancy and male sterilisation all of which recorded zero percent usage in current or past time periods. 
Table 6. Respondents' declared major sources of awareness or information on the seven identified barrier or natural methods of birth control methods using frequency analysis.

\begin{tabular}{|c|c|c|c|}
\hline Birth control method & $\begin{array}{l}\text { First most important } \\
\text { source of information }\end{array}$ & $\begin{array}{c}\text { Second most important source } \\
\text { of information }\end{array}$ & $\begin{array}{l}\text { Third most important } \\
\text { source of information }\end{array}$ \\
\hline Male condom & $\begin{array}{c}\text { Television advertisements } \\
\text { (71.4\%) }\end{array}$ & Radio (48.2\%) & $\begin{array}{l}\text { Peers and friends } \\
\quad(43.8 \%)\end{array}$ \\
\hline Female condom & $\begin{array}{c}\text { Television advertisements } \\
\text { (47.3\%) }\end{array}$ & $\begin{array}{l}\text { Hospitals and clinics } \\
\text { (42.9\%) }\end{array}$ & $\begin{array}{l}\text { Peers and friends } \\
\quad(31.2 \%)\end{array}$ \\
\hline Breastfeeding & $\begin{array}{l}\text { Hospitals and clinics } \\
\text { (55.0\%) }\end{array}$ & $\begin{array}{l}\text { Sex education in schools } \\
(18.3 \%)\end{array}$ & $\begin{array}{c}\text { Television advertisements } \\
(15.0 \%)\end{array}$ \\
\hline Foaming tablets & $\begin{array}{l}\text { Hospitals and clinics } \\
\text { (38.5\%) }\end{array}$ & $\begin{array}{l}\text { Peers and friends } \\
\quad(31.8 \%)\end{array}$ & $\begin{array}{c}\text { Television advertisements } \\
\text { (22.5\%) }\end{array}$ \\
\hline Rhythm & $\begin{array}{l}\text { Peers and friends } \\
\quad(51.3 \%)\end{array}$ & $\begin{array}{l}\text { Sex education in schools } \\
(30.7 \%)\end{array}$ & $\begin{array}{l}\text { Hospitals and clinics } \\
\text { (23.2\%) }\end{array}$ \\
\hline Withdrawal before ejaculation & $\begin{array}{l}\text { Peers and friends } \\
\quad(69.6 \%)\end{array}$ & $\begin{array}{l}\text { Sex education in schools } \\
(18.5 \%)\end{array}$ & $\begin{array}{l}\text { Hospitals and clinics } \\
\text { (7.7\%) }\end{array}$ \\
\hline $\begin{array}{l}\text { Traditional method based on the planned } \\
\text { abstinence with the woman staying away } \\
\text { from partner for a period of time }\end{array}$ & $\begin{array}{l}\text { Peers and friends } \\
\quad(53.7 \%)\end{array}$ & $\begin{array}{l}\text { Parents, carers and older relatives } \\
\text { (35.9\%) }\end{array}$ & $\begin{array}{l}\text { Hospitals and clinics } \\
\qquad(18.0 \%)\end{array}$ \\
\hline
\end{tabular}

Note: The figures in parentheses are the proportions of respondents using that information source.

Table 7. Popularity of specific birth control methods over various time periods based on the proportions of users of birth control methods using a particular method and involving only the 84 respondents who had ever used a birth control method.

\begin{tabular}{|c|c|c|c|}
\hline No. & Birth control method & $\begin{array}{l}\text { Current use that is within } 12 \\
\text { months preceding the survey (\%) }\end{array}$ & $\begin{array}{l}\text { Used in the past meaning more than } \\
\text { one year preceding the survey (\%) }\end{array}$ \\
\hline 1. & Rhythm or calendar method & 42.5 & 10.8 \\
\hline 2. & Withdrawal before ejaculation & 41.3 & 11.1 \\
\hline 3. & Dual protection with use of male condom & 21.7 & 30.5 \\
\hline 4. & Injectable method & 9.5 & 8.5 \\
\hline 5. & Female pill & 7.2 & 17.1 \\
\hline 6. & Emergency contraception pill & 7.2 & 6.0 \\
\hline 7. & $\begin{array}{l}\text { Lactational amenorrhea method/ } \\
\text { breastfeeding method }\end{array}$ & 7.2 & 4.8 \\
\hline 8. & Female condom & 4.8 & 2.4 \\
\hline 9. & Implant & 4.8 & 0.0 \\
\hline 10. & IUD/coil/diaphragm & 2.4 & 0.0 \\
\hline 11. & Illegal abortion & 1.2 & 18.1 \\
\hline 12. & Foaming tablet & 1.2 & 4.8 \\
\hline 13 & Traditional herbs & 1.2 & 2.4 \\
\hline 14. & Legal abortion & 1.2 & 0.0 \\
\hline 15. & $\begin{array}{l}\text { Traditional birth control based on planned } \\
\text { abstinence from husband }\end{array}$ & 0.0 & 2.4 \\
\hline 16. & Female sterilisation & 0.0 & 0.0 \\
\hline 17. & $\begin{array}{c}\text { Men taking hormonal and related medicine to } \\
\text { prevent pregnancy }\end{array}$ & 0.0 & 0.0 \\
\hline 18. & Male sterilisation & 0.0 & 0.0 \\
\hline
\end{tabular}




\subsection{Attributes Influencing Choice of Specific Birth Control Methods}

As reported in the literature review, the choice of a birth control method, similar to other consumer products, is influenced greatly by the attributes embodied in the birth control method in line with the Lancaster demand theory. The survey elicited information from the 84 current and past users of various birth control methods on the key attributes that influenced their decision to choose and use specific methods. The attributes elicited included affordability and price, availability of product locally, low travel costs to pharmacy or clinic, access to adequate information about product, ease of inserting item into body, comfort in having item inside body, reliability in preventing pregnancy, safety in terms of minimal side effects, acceptance by male partner or spouse, peer influence and confidentiality and no embarrassment to either male or female partner in using the product.

As indicated in Table 7, only seven birth control methods were popularly used by the respondents. These are 1) dual protection with the male wearing condom, 2) rhythm or calendar method, 3) withdrawal before ejaculation, 4) illegal abortion, 5) female pill, 6) injectable medicine and 7) emergency contraception. The importance of the attributes in the choice of the use of these seven birth control methods is summarised in Tables 8-14 respectively. It is clear that access to adequate information about the product was considered the most important attribute for the choice of the specific birth control method for all seven methods except for illegal abortion and emergency contraception pill (refer to Tables 8-14). For the latter two methods, their known reliability in ending pregnancy, was considered the most important attribute followed by the adequate information about the product attribute. Overall, for all the seven methods, safety in terms of minimal side effects and the ease of inserting into the body were considered the next two important attributes. The attribute, acceptance by the male partner or

Table 8. Average numerical ranking of the importance of attributes in the choice of the dual protection with male wearing condoms.

\begin{tabular}{|cccccc}
\hline No. & Attribute & No. & $\begin{array}{c}\text { Average score } \\
\text { of importance }\end{array}$ & $\begin{array}{c}\text { Standard deviation } \\
\text { of score }\end{array}$ & $\begin{array}{c}\text { Coefficient of } \\
\text { variation }\end{array}$ \\
\hline $\mathbf{1}$ & Access to adequate information about product & 47 & 4.85 & 0.625 & 0.129 \\
$\mathbf{2}$ & Low travel costs to pharmacy or clinic & 47 & 4.79 & 0.778 & 0.162 \\
$\mathbf{3}$ & Acceptance by male partner or spouse & 48 & 4.75 & 0.863 & 0.182 \\
$\mathbf{4}$ & Ease of inserting item into body & 42 & 4.74 & 0.828 & 0.175 \\
$\mathbf{5}$ & Reliability in preventing pregnancy & 49 & 4.71 & 0.707 & 0.150 \\
$\mathbf{6}$ & Availability of product locally & 47 & 4.70 & 0.998 & 0.212 \\
$\mathbf{7}$ & Confidentiality and no embarrassment & 44 & 4.66 & 1.099 & 0.236 \\
$\mathbf{8}$ & Safety in terms of minimal side effects & 48 & 4.54 & 1.254 & 0.276 \\
$\mathbf{9}$ & Comfort in having item inside body & 43 & 4.33 & 1.410 & 0.326 \\
$\mathbf{1 0}$ & Affordability and price & 47 & 3.30 & 1.876 & 0.568 \\
\hline
\end{tabular}

Notes: A score of 5 indicates “very high level of importance”, 4 is "high level of importance”, 3 is “moderately important”, 2 is "low level of importance" and 1 "very low level of importance.

Table 9. Average numerical ranking of the importance of attributes in the choice of the rhythm or calendar method.

\begin{tabular}{rccccc}
\hline No. & Attribute & No. & $\begin{array}{c}\text { Average score of } \\
\text { importance }\end{array}$ & $\begin{array}{c}\text { Standard deviation of } \\
\text { score }\end{array}$ & $\begin{array}{c}\text { Coefficient of } \\
\text { variation }\end{array}$ \\
\hline $\mathbf{1}$ & Access to adequate information about product & 40 & 4.95 & 0.221 & 0.045 \\
$\mathbf{2}$ & Confidentiality and no embarrassment & 41 & 4.90 & 0.490 & 0.100 \\
$\mathbf{3}$ & Safety in terms of minimal side effects & 44 & 4.73 & 1.020 & 0.216 \\
$\mathbf{4}$ & Acceptance by male partner or spouse & 42 & 4.43 & 1.417 & 0.320 \\
$\mathbf{5}$ & Reliability in preventing pregnancy & 45 & 4.36 & 1.246 & 0.286 \\
$\mathbf{6}$ & Affordability and price & 39 & 3.97 & 1.724 & 0.434 \\
\hline
\end{tabular}

Notes: A score of 5 indicates "very high level of importance", 4 is "high level of importance", 3 is "moderately important”, 2 is "low level of importance" and 1 "very low level of importance. 
Table 10. Average numerical ranking of the importance of attributes in the choice of withdrawal method.

\begin{tabular}{rccccc}
\hline No. & Attribute & No. & $\begin{array}{c}\text { Average score of } \\
\text { importance }\end{array}$ & $\begin{array}{c}\text { Standard deviation of } \\
\text { score }\end{array}$ & $\begin{array}{c}\text { Coefficient of } \\
\text { variation }\end{array}$ \\
\hline $\mathbf{1}$ & Access to adequate information about product & 24 & 5.00 & 0.000 & 0.000 \\
$\mathbf{2}$ & Safety in terms of minimal side effects & 33 & 4.85 & 0.712 & 0.147 \\
$\mathbf{3}$ & Confidentiality and no embarrassment & 32 & 4.84 & 0.723 & 0.149 \\
$\mathbf{4}$ & Acceptance by male partner or spouse & 33 & 4.82 & 0.727 & 0.151 \\
$\mathbf{5}$ & Reliability in preventing pregnancy & 32 & 4.66 & 0.827 & 0.177 \\
$\mathbf{6}$ & Affordability and price & 29 & 3.72 & 1.869 & 0.502 \\
\hline
\end{tabular}

Notes: A score of 5 indicates “very high level of importance”, 4 is "high level of importance”, 3 is “moderately important”, 2 is "low level of importance" and 1 "very low level of importance.

Table 11. Average numerical ranking of the importance of attributes in the choice of illegal abortion.

\begin{tabular}{lccccc}
\hline No. & Attribute & No. & $\begin{array}{c}\text { Average score of } \\
\text { importance }\end{array}$ & $\begin{array}{c}\text { Standard deviation of } \\
\text { score }\end{array}$ & $\begin{array}{c}\text { Coefficient of } \\
\text { variation }\end{array}$ \\
\hline $\mathbf{1}$ & Reliability in ending pregnancy & 18 & 4.61 & 1.145 & 0.248 \\
$\mathbf{2}$ & Access to adequate information about product & 18 & 4.39 & 1.335 & 0.304 \\
$\mathbf{3}$ & Confidentiality and no embarrassment & 18 & 4.00 & 1.715 & 0.429 \\
$\mathbf{4}$ & Acceptance by male partner or spouse & 18 & 3.89 & 1.844 & 0.474 \\
$\mathbf{5}$ & Safety in terms of minimal side effects & 18 & 3.83 & 1.757 & 0.459 \\
$\mathbf{6}$ & Availability of product locally & 18 & 3.56 & 1.688 & 0.474 \\
$\mathbf{7}$ & Comfort in having item inside body & 17 & 2.53 & 1.940 & 0.767 \\
$\mathbf{8}$ & Low travel costs to pharmacy or clinic or hospital & 17 & 2.47 & 1.940 & 0.785 \\
$\mathbf{9}$ & Ease of inserting item into body & 15 & 2.13 & 1.807 & 0.848 \\
$\mathbf{1 0}$ & Affordability and price & 18 & 1.89 & 1.711 & 0.905 \\
\hline
\end{tabular}

Note: A score of 5 indicates "very high level of importance", 4 is "high level of importance", 3 is "moderately important", 2 is "low level of importance" and 1 "very low level of importance.

Table 12. Average numerical ranking of the importance of attributes in the choice of female pill.

\begin{tabular}{lccccc}
\hline No. & Attribute & No. & $\begin{array}{c}\text { Average score of } \\
\text { importance }\end{array}$ & $\begin{array}{c}\text { Standard deviation of } \\
\text { score }\end{array}$ & $\begin{array}{c}\text { Coefficient of } \\
\text { variation }\end{array}$ \\
\hline $\mathbf{1}$ & Access to adequate information about product & 17 & 4.94 & 0.243 & 0.049 \\
$\mathbf{2}$ & Reliability in preventing pregnancy & 20 & 4.75 & 0.786 & 0.165 \\
$\mathbf{3}$ & Ease of inserting item into body & 13 & 4.69 & 1.109 & 0.236 \\
$\mathbf{4}$ & Low travel costs to pharmacy or clinic & 18 & 4.67 & 0.840 & 0.180 \\
$\mathbf{5}$ & Availability of product locally & 18 & 4.61 & 0.778 & 0.169 \\
$\mathbf{6}$ & Comfort in having item inside body & 14 & 4.57 & 1.158 & 0.253 \\
$\mathbf{7}$ & Confidentiality and no embarrassment & 16 & 4.19 & 1.601 & 0.382 \\
$\mathbf{8}$ & Safety in terms of minimal side effects & 18 & 3.72 & 1.406 & 0.378 \\
$\mathbf{9}$ & Affordability and price & 18 & 3.56 & 1.886 & 0.530 \\
$\mathbf{1 0}$ & Acceptance by male partner or spouse & 17 & 3.00 & 1.904 & 0.635 \\
\hline
\end{tabular}

Notes: A score of 5 indicates "very high level of importance”, 4 is "high level of importance”, 3 is “moderately important”, 2 is "low level of importance" and 1 "very low level of importance. 
Table 13. Average numerical ranking of the importance of attributes in the choice of injectable medicine.

\begin{tabular}{|c|c|c|c|c|c|}
\hline No. & Attribute & No. & $\begin{array}{c}\text { Average score of } \\
\text { importance }\end{array}$ & $\begin{array}{c}\text { Standard deviation of } \\
\text { score }\end{array}$ & $\begin{array}{c}\text { Coefficient of } \\
\text { variation }\end{array}$ \\
\hline 1 & Access to adequate information about product & 16 & 4.69 & 0.793 & 0.169 \\
\hline 2 & Availability of product locally & 16 & 4.69 & 1.014 & 0.216 \\
\hline 3 & Reliability in preventing pregnancy & 16 & 4.69 & 1.014 & 0.216 \\
\hline 4 & Low travel costs to pharmacy or clinic & 16 & 4.56 & 1.094 & 0.240 \\
\hline 5 & Confidentiality and no embarrassment & 17 & 4.53 & 0.943 & 0.208 \\
\hline 6 & Ease of inserting item into body & 15 & 4.40 & 1.183 & 0.269 \\
\hline 7 & Safety in terms of minimal side effects & 16 & 4.19 & 1.424 & 0.340 \\
\hline 8 & Acceptance by male partner or spouse & 16 & 4.19 & 1.601 & 0.382 \\
\hline 9 & Comfort in having item inside body & 15 & 3.93 & 1.710 & 0.435 \\
\hline 10 & Affordability and price & 15 & 3.33 & 1.839 & 0.552 \\
\hline
\end{tabular}

Note: A score of 5 indicates "very high level of importance", 4 is "high level of importance”, 3 is "moderately important”, 2 is "low level of importance" and 1 "very low level of importance.

Table 14. Average numerical ranking of the importance of attributes in the choice of emergency contraception.

\begin{tabular}{lccccc}
\hline No. & Attribute & No. & $\begin{array}{c}\text { Average score of } \\
\text { importance }\end{array}$ & $\begin{array}{c}\text { Standard deviation of } \\
\text { score }\end{array}$ & $\begin{array}{c}\text { Coefficient of } \\
\text { variation }\end{array}$ \\
\hline $\mathbf{1}$ & Reliability in preventing pregnancy & 13 & 5.00 & 0.000 & 0.000 \\
$\mathbf{2}$ & Access to adequate information about product & 13 & 4.92 & 0.277 & 0.056 \\
$\mathbf{3}$ & Ease of inserting item into body & 11 & 4.64 & 0.924 & 0.199 \\
$\mathbf{4}$ & Low travel costs to pharmacy or clinic & 12 & 4.50 & 1.243 & 0.276 \\
$\mathbf{5}$ & Availability of product locally & 13 & 4.46 & 1.198 & 0.269 \\
$\mathbf{6}$ & Affordability and price & 12 & 4.42 & 1.379 & 0.312 \\
$\mathbf{7}$ & Confidentiality and no embarrassment & 12 & 4.33 & 1.073 & 0.248 \\
$\mathbf{8}$ & Safety in terms of minimal side effects & 12 & 4.25 & 1.422 & 0.335 \\
$\mathbf{9}$ & Comfort in having item inside body & 12 & 4.17 & 1.528 & 0.366 \\
$\mathbf{1 0}$ & Acceptance by male partner or spouse & 13 & 3.77 & 1.691 & 0.449 \\
\hline
\end{tabular}

Notes: A score of 5 indicates “very high level of importance”, 4 is "high level of importance”, 3 is "moderately important”, 2 is "low level of importance" and 1 "very low level of importance.

spouse, was ranked highly but was not the most important attribute for any of the seven birth control methods. This attribute was also ranked the lowest for the female pill and emergency contraception pill. This result suggested that power relationship between the woman and her male partner or spouse was not the most important factor influencing the choice of contraceptives by the woman. For all seven birth control methods, the relatively moderate ranking assigned to affordability and price attribute reflected the subsidisation of contraceptives which made them relatively affordable to the population.

\subsection{Results of the Regression Analysis of Awareness and Use of Birth Control Methods}

Table 15 provides the results of the generalised Tobit regression model analysis of the factors influencing the awareness of and use of birth control methods by the respondents. The results from the component Tobit regression model showed that specific awareness of the birth control methods, being in a current sexual relationship with a partner and the number of children that a woman had significantly and positively influenced the likelihood of her using birth control methods. Students were significantly less likely to use birth control methods than non-students due to the desire for abstinence from sex in order to complete their studies as indicated by several students during the interviewing process. 
Table 15. Results of the Generalised Tobit regression analysis of woman's use or non-use of birth control methods. (a) The dependent variable of the first part of the model is EVERUSEBCM and it was estimated using the probit model; (b) The dependent variable of the second part of the model is AWARENESS1 and this was estimated by maximum likelihood procedure.

(a)

\begin{tabular}{cccc}
\hline Explanatory variable & Parameter estimate (B) & Student t value & Probability level of significance \\
\hline CONSTANT & -4.934 & -10.544 & $0.000^{*}$ \\
AWARENESS2 & 1.001 & 9.817 & $0.000^{*}$ \\
CSEXRELA & 0.305 & 9.813 & $0.000^{*}$ \\
NCHILD & 0.174 & 9.816 & $0.000^{*}$ \\
EDU & 0.050 & 1.153 & 0.249 \\
STUDENT & -0.095 & -9.601 & $0.000^{*}$ \\
\hline
\end{tabular}

(b)

\begin{tabular}{cccc}
\hline Explanatory variable & Parameter estimate (B) & Student $\mathbf{t}$ value & Probability level of significance \\
\hline CONSTANT & 3.861 & 18.265 & $0.000^{*}$ \\
AGE & 0.011 & 342.601 & $0.000^{*}$ \\
EDU & 0.001 & 0.032 & 0.974 \\
SIGMA & 0.904 & 9.818 & $0.000^{*}$ \\
\hline
\end{tabular}

Notes: The sample size available for the analysis was 110 due to missing values for some variables. *Parameter was statistically significant at the $5 \%$ confidence level used for the study.

The general awareness of birth control methods regression analysis indicated that increasing age of the woman led to increased general awareness of birth control methods as shown by another study [47]. However, our finding, in contrast to the previous study, indicated that the level of educational attainment of the woman per se did not significantly influence the level of general awareness of birth control methods. The results of our study dealing with actual use of birth control methods are corroborated by Casterline et al. (2001), who in their study on obstacles to contraceptive use in Pakistan, established that lack of knowledge and awareness was one of the major obstacles to contraceptive usage. They asserted that as more people increased their knowledge on birth control they were likely to use birth control methods. The findings of Rustagi et al. (2010) also supported the positive relationship between use of birth control methods and awareness [48]. On the other hand, a positive relationship between current marriage status and use of birth control methods is shown in another study [49]. This result is in contrast to the results of our study which rather showed a positive relationship between the number of children that a woman had and use of birth control methods instead of her marriage status.

\section{Conclusions}

The study reported in this paper was a highly-confidential survey undertaken to assess the awareness of and factors influencing the use of birth control methods among 120 women aged between 15 and 49 years, in their reproductive lifespan. The results of the analysis indicated that all the 120 women respondents were aware of at least one birth control method. Altogether, 18 birth control methods were identified. Increasing age was the main factor responsible for the general level of awareness of birth control methods. Use of birth control methods was significantly and positively related to the level of awareness of birth control methods, being in a current sexual relationship, and the number of children that the woman had.

Students were less likely to use birth control methods than non-students suggesting recognition of temporary abstinence from sex as alternative birth control method. However, the relatively low awareness of birth control methods exhibited by relatively younger women suggested the need of government and non-governmental organisations to establish and/or expand programmes related to sex education and family planning for younger women through outreach programmes in churches, schools and community-operated social centres and institutions such as the local government offices. Community sensitization programmes should be persistently undertaken to clear misconceptions on birth control methods especially on the female condom. The low level of awareness of the traditional Ghanaian method of abstinence from husband/partner for several months after delivery of baby by women should be tackled through the provision of more information on this method by hospi- 
tals and clinics to pregnant and nursing mothers and those who attend pre-natal counselling sessions at urban and peri-urban health centres. Finally, future studies on the use of contraceptives in Ghana need to analyse in more detail the influence of career choices made by women on the use of contraceptives as undertaken elsewhere in the world [50].

\section{References}

[1] Planned Parenthood Federation of America (2012) A History of Birth Control Methods. Planned Parenthood Federation of America, New York.

[2] United Nations Department of Economic and Social Affairs Population Division (2011) World Contraceptive Use 2010. United Nations, New York.

[3] Darroch, J.E. (2013) Trends in Contraceptive Use. Contraception, 87, 259-263. http://dx.doi.org/10.1016/j.contraception.2012.08.029

[4] Darroch, J.E. and Singh, S. (2013) Trends in Contraceptive Need and Use in Developing Countries in 2003, 2008, 2012: An Analysis of National Surveys. Lancet, 381, 56-62. http://dx.doi.org/10.1016/S0140-6736(13)60597-8

[5] Asante-Sarpong, H. (2007) From Their Own Perspective: Perceptions of Women about Modern and Natural/Traditional Methods of Contraception in Koforidua and Asokore in the Eastern Region of Ghana. Norwegian University of Science and Technology, Trondheim.

[6] Health Policy Project (2012) Resource Requirements for Family Planning in Ghana. Health Policy Project, Washington DC.

[7] Ghana Statistical Service (GSS) (2013) 2010 Population and Housing Census: National Analytical Report. GSS, Accra.

[8] Ghana Statistical Service (GSS) (2013) 2010 Population and Housing Census: Regional Analytical Report Greater Accra Region. GSS, Accra.

[9] National Population Council (NPC) (2004) Fact Sheet Number 1: Population of Ghana-National Trends. NPC, Accra.

[10] Oliver, R. (1995) Contraceptive Use in Ghana: The Role of Service Availability, Quality, and Price. World Bank, Washington DC. http://dx.doi.org/10.1596/0-8213-3020-9

[11] Hesse, S. (2007) Assessing Facility Readiness of Family Planning Services in Ghana. Emory University School of Public Health, Atlanta.

[12] Ghana Health Service (GHS) (2008) Questions and Answers on Long Acting and Permanent Family Planning Methods, Health Promotion Department and, Reproductive and Child Health Development. GHS, Accra.

[13] Ann, K., Blanc, C. and Steve, G. (2002) Greater than Expected Fertility Decline in Ghana: Untangling a Puzzle. Journal of Biosocial Science, 34, 475-495. http://dx.doi.org/10.1017/S0021932002004753

[14] Ghana Statistical Service (GSS) (2004) Ghana Demographic and Health Survey 2003. GSS, Accra.

[15] Caldwell, J.C. (1979) Education as a Factor in Mortality Decline: An Examination of Nigerian Data. Population Studies, 33, 395-413. http://dx.doi.org/10.2307/2173888

[16] Dyson, T. and Moore, M. (1983) On Kinship Structure, Female Autonomy and Demographic Behaviour in India. Population and Development Review, 9, 35-60. http://dx.doi.org/10.2307/1972894

[17] Cochrane, S.H. (1979) Fertility and Education: What Do We Really Know? Johns Hopkins University Press, Baltimore.

[18] Sanger, M. (1931) My Fight for Birth Control. Maxwell Company, New York.

[19] Ajani, S.T. (2013) Islamic Perspectives on Birth Control. American International Journal of Contemporary Research, 3, 117-127.

[20] Trussell, J. (2011) Contraceptive Failure in the United States. Contraception, 83, 397-404. http://dx.doi.org/10.1016/j.contraception.2011.01.021

[21] Lessard, L.N., Karasek, D., Ma, S., Darney, P., Deardorff, J., Lahiff, M., Grossman, D. and Foster, D.G. (2012) Contraceptive Features Preferred by Women at High Risk of Unintended Pregnancy. Perspectives on Sexual and Reproductive Health, 44, 194-200. http://dx.doi.org/10.1363/4419412

[22] Smith, R. (2010) Contemporary Hysteroscopic Methods for Female Sterilisation. International Journal of Gynaecology and Obstetrics, 108, 79-84. http://dx.doi.org/10.1016/j.ijgo.2009.07.026

[23] Bernstein, S. and Hansen, C.J. (2006) Public Choices, Private Decisions: Sexual and Reproductive Health and the Millennium Development Goals. United Nations Millennium Project, New York.

[24] World Bank (2004) A Review of Population, Reproductive Health, and Adolescent Health and Development in Poverty Reduction Strategies. World Bank, Washington DC. 
[25] World Health Organization (WHO) (1971) Health Education in Health Aspects of Family Planning: Report of a WHO Study Group. WHO Technical Report Series No. 483. WHO, Geneva.

[26] Aboyeji, A.P., Fawole, A.A. and Ijaiya, N.A. (2001) Knowledge and Previous Contraceptive Use by Pregnant Teenagers in Ilorin, Nigeria. Tropical Journal Obstetric Gynecology, 18, 73-77. http://dx.doi.org/10.4314/tjog.v18i2.14434

[27] Opoku, B. and Kwaununu, F. (2011) Knowledge and Practices of Emergency Contraception among Ghanaian Women. African Journal of Reproductive Health, 15, 147-152.

[28] Tsui, A.O. (1985) Community Effects on Contraceptive Use. In: Casterline, J.B., Ed., The Collection and Analysis of Community Data, International Statistical Institute, Voorburg.

[29] Adjei, D., Sarfo, J.O., Asiedu, M. and Sarfo, I.A. (2014) Psychosocial Factors Affecting Contraceptive Usage: A Case of Unmet Needs in Ghana. European Scientific Journal, 10, 84-93.

[30] Okech, T.C., Wawire, N.W. and Mburu, T.K. (2011) Contraceptive Use among Women of Reproductive Age in Kenya’s City Slums. International Journal of Business and Social Science, 2, 22-43.

[31] Oyedokun, A.O. (2007) Determinants of Contraceptive Usage: Lessons from Women in Osun State, Nigeria. Journal of Humanities and Social Sciences, 1, 1-14.

[32] Kulczycki, A. (2008) Husband-Wife Agreement, Power Relations and Contraceptive Use in Turkey. International Family Planning Perspectives, 34, 127-137. http://dx.doi.org/10.1363/3412708

[33] Lancaster, K.J. (1966) A New Approach to Consumer Theory. Journal of Political Economy, 74, 132-157. http://dx.doi.org/10.1086/259131

[34] Garcia, S.G., Snow, R. and Aitken, I. (1997) Preferences for Contraceptive Attributes: Women in Cuidad Juarez, Mexico. International Family Planning Perspectives, 23, 52-58. http://dx.doi.org/10.2307/2950824

[35] Casterline, J.B., Sathar, Z.A. and Haque, M. (2001) Obstacles to Contraceptive Use in Pakistan: A Study in Punjab. Studies in Family Planning, 32, 95-110. http://dx.doi.org/10.1111/j.1728-4465.2001.00095.x

[36] Ghana Health Service (GHS) (2006) A Road Map for Repositioning Family Planning in Ghana. GHS, Accra.

[37] Moore, K.A., Simms, M.C. and Betsey, C.L. (1986) Choice and Circumstance: Racial Differences in Adolescent Sexuality and Fertility. Transaction Publishers, New York.

[38] Hartmann, B. (1995) Reproductive Rights and Wrongs: The Global Politics of Population Control. Harper and Row, New York.

[39] Anaman, K.A. (2014) Research Methods in Economics and Other Social Sciences Second Edition. Lambert Academic Publishing, Saarbrucken.

[40] Anaman, K.A. and Nyadzi, W.B. (2015) Analysis of Improper Disposal of Solid Wastes in a Low-Income Area of Accra, Ghana. Applied Economics and Finance, 2, 66-75.

[41] Anaman, K.A. and Kassim, H.M. (2006) Marriage and Female Labour Supply in Brunei Darussalam: A Case Study of Urban Women in Bandar Seri Begawan. The Journal of Socio-Economics, 35, 797-812. http://dx.doi.org/10.1016/j.socec.2005.11.038

[42] Anaman, K.A. and Amin, N.R.A. (2005) Determinants of Household and Government Health Expenditures in Brunei Darussalam. Journal of Economics, Management and Accounting, 13, 139-166.

[43] Yamane, T. (1973) Statistics: An Introductory Analysis. 3rd Edition, Harper and Row, New York.

[44] Tobin, J. (1958) Estimation of Relationships for Limited Dependent Variables. Econometrica, 31, 24-36. http://dx.doi.org/10.2307/1907382

[45] Heckman, J.J. (1974) Sample Selection Bias as a Specification Error. Econometrica, 47, 153-162. http://dx.doi.org/10.2307/1912352

[46] Hall, B.H. and Cummins, C. (2009) Time Series Processor (TSP) Version 5 Reference Manual. TSP Company, Palo Alto.

[47] Arbab, A.A., Bener, A. and Abdulmalik, M. (2011) Prevalence, Awareness and Determinants of Contraceptive Use in Qatari Women. Eastern Mediterranean Health Journal, 17, 11-18.

[48] Rustagi, N., Taneja, D.K., Kaur, R. and Ingle, G.K. (2010) Factors Affecting Contraception among Women in a Minority Community in Delhi: A Qualitative Study. Health and Population: Perspectives and Issues, 33, 10-15.

[49] Fasina, F.F., Ogunnaike, O.O. and Ogbari, M. (2011) Socio-Economic Variables and Contraceptive Usage: Implication for Social Marketing. International Journal of Management \& Business Studies, 1, 21-24.

[50] Goldin, C. and Katz, L.F. (2002) The Power of the Pill: Oral Contraceptives and Women's Career and Marriage Decisions. Journal of Political Economy, 110, 730-770. http://dx.doi.org/10.1086/340778 